\title{
The Dynamic Forest Commons of Central America: New Directions for Research
}

\author{
Iliana Monterroso \\ Rights and Resources Initiative and Latin American \\ Faculty of Social Sciences - FLACSO \\ Guatemala City
}

Anne M. Larson

Center for International Forestry Research

Managua, Nicaragua

\begin{abstract}
This article reviews research on forests in Central America under the lens of common pool resources literature. It briefly presents research in the region and highlights some limitations of the majority of common property scholarship. The article draws on three case studies in Guatemala and Nicaragua that were part of a study on forest tenure reforms in 2006-2009 to demonstrate the need to expand beyond the traditional questions and methods of common property research. It argues that greater attention must be given to the dynamic, historical processes that produce boundaries and institutions, rather than accepting these as givens.

Keywords: common property, community forests, tenure rights, Central America, Nicaragua, Guatemala

\section{Resumen}

El presente artículo hace una revisión de la investigación en Centroamérica en materia de bosques desde la perspectiva de la teoría de los recursos de uso común. Se inicia con una revisión breve de los trabajos de investigación realizados a nivel regional y después se resaltan algunas limitaciones de la mayoría de los estudios sobre propiedad común. El artículo se enfoca en el análisis de tres casos de estudio en Guatemala y Nicaragua que fueron parte de un estudio sobre reformas de tenencia en los bosques realizado entre el 2006 y el 2009 para demostrar la necesidad de ampliar las reflexiones más allá de las preguntas y los métodos utilizados en la investigación sobre la propiedad comunal. Se argumenta que hay que incorporar en el análisis temas vinculados a la dinámica y los procesos históricos que producen instituciones y límites en vez de inferir estos aspectos como dados.

Palabras clave: propiedad común, bosques comunitarios, derechos de propiedad, América Central, Nicaragua, Guatemala
\end{abstract}




\section{Introduction}

An important part of Central America's forests are located on land under formal or customary common property regimes. In Nicaragua, about 2.2 million hectares have been titled to indigenous territories and almost 1.5 million ha more are in process (Procuraduría General de la República 2010), for a total of some 30 percent of the country's land area. Most of this land is forested. About 750,000 ha of forests are located on indigenous comarcas in Panama, about one third of the national forested area (ANAM 2009, PROARCA 2005). In Guatemala, some 400,000 ha are under community forest concessions in the Petén, and another 1.2 million ha are under other forms of communal property, representing about half of the total forest area in the country (Grupo Promotor 2009; PROARCA 2005). In Honduras, 37 community forest managements contracts had been signed with organized community groups for over 300,000 ha by 2011 (ICF 2011).

In spite of this fairly significant area under collective management regimes in the region, research from the perspective of the common property school has been limited, probably due in part to the greater emphasis on agrarian lands in development and in academic research in Latin America. It is only fairly recently that forests have taken center stage in land reforms (Pacheco et al. 2008; Pacheco and Barry 2009), such that about 25 percent of Latin America's forests are now owned by communities and indigenous people and another 7 percent designated for their use; this represents a total of some 201 million ha of forest in the hands of these actors in 2008 and an increase of 67 million ha since 2002 (RRI and ITTO 2009).

The vast majority of common property research, which we refer to here as traditional common property research ${ }^{1}$, is focused on understanding and promoting the emergence of collective institutions (understood as rules) for the improved management of common property resources (Agrawal 2003; Ostrom 2009). It is based on methodological individualism whereby individual behavior is based on rational choice (Johnson 2004; McCay 2002; Peters 1987) and where individuals and property systems "stand above politics" (Agrawal 2003: 244). Thus institutions evolve or are designed and property boundaries are given or negotiated (Agrawal 2005; Finley-Brook and Offen 2009; Taylor 2009).

The forest commons of Central America call for more dynamic, historically grounded approaches. These landscapes have often been shaped through local, national and in some cases international struggles that have resulted in the formal recognition of property rights - and they continue to be shaped by ongoing challenges and negotiation processes. The goal of this article is to highlight how future research on the commons needs to pay greater attention to history and change over time, conflict and negotiation with multiple actors at multiple scales, and the dynamic production of space and boundaries. Empirical data comes from research conducted in three sites that were part of a study on tenure reforms undertaken from 2006 to 2009 by the Center for International Forestry Research (CIFOR) and the Rights and Resources Initiative (RRI). The sites include the lowland community forestry concessions of the 
Petén, Guatemala, the communal forests of the western Guatemalan highlands, and the indigenous territories of Nicaragua's lowland Caribbean Coast.

The next section briefly reviews research on the commons in Central America to date, then draws on critical commons scholars to discuss the limitations of traditional research in the field. The third section presents the research methods for the cases presented here and the three case studies. The last section argues for the need for new research questions and approaches for understanding the region's commons in light of the cases.

\section{Commons Research in Central America}

In spite of the fairly significant forest area - at least 6 million hectares (RRI and ITTO 2009, ICF 2011, Procuradoria, Grupo Promotor 2009) out of the 18 million hectares with forest cover in the region (PROARCA 2005) under collective management regimes in Central America, research on these forests from the perspective of the common property school has been fairly limited. Rather, agricultural lands have been the primary interest of academics and practitioners in the region, probably due to the importance of agrarian issues: the limited availability of land for rural peasants, the colonial legacy of the latifundio-minifundio structure in Latin American history and the importance of these lands in the region's revolutionary movements (de Janvry 1989; Eckstein, S 2001; Enriquez 1991; Gauster and Isakson 2007; Gliejeses 1989). Hence these priorities have overshadowed research on forests commons and government policy (Thiesenhusen 1989), at least until recently (Pacheco et al. 2008; Pacheco and Barry 2009).

The Central America literature on forest commons has focused on two central questions: (1) under what conditions do collective institutions, specifically rules for resource management, emerge?; and, (2) how do different tenure regimes, types of users or approaches to forest management (such as protected areas) compare regarding outcomes for forests? With regard to the first question, Gibson (2001) compared two sites in Guatemala and found that scarcity and resource dependence led to the emergence of collective resource management rules. Tucker et al. (2007), in a comparative study of nine forests and a variety of institutional arrangements in Guatemala and Honduras, found that biophysical characteristics favoring higher productivity represented an important incentive for developing stronger institutional mechanisms.

With regard to the second question, research comparing private and communal regimes of forest management found that neither type of forest owner - private or communal- prioritizes sustainable forest management techniques (Tucker 1999). Other studies have focused specifically on the distinction between indigenous and non-indigenous management, suggesting that recognizing forest land rights for indigenous groups is more effective than enforcement approaches based on command and control (Richards 1997; Stocks et al. 2007; Hayes 2007, 2006). Finally, recent studies on protected areas (Bray et al. 2008; Radachowsky et al. 2012) suggest that understanding changing contexts 
and histories of user groups as well as greater perceived legitimacy of decision making processes (Monterroso and Barry 2012) are also important elements that influence management outcomes.

While these articles have made important contributions to research on the commons, we argue that future research should move beyond traditional common property questions and methods to further improve our understanding of forest governance and its challenges in Central America. Several other commons scholars (Peters 1987; Goldman 1997; McCay 1987, 2002; McCay and Jentoft 1998; Agrawal 2002, 2005, 2007) have put forward similar arguments, contrasting the traditional approach with the need for greater attention to contextual, historical and power issues. This section focuses on four limiting issues, characteristic of commons research, raised by these scholars that are directly relevant to the cases presented here.

First, the nature of the questions asked and the overall goals of traditional commons research may lose site of the bigger picture. Traditional commons scholars are interested in how to improve resource management (Johnson, 2004) and create durable common property regimes (Agrawal 2002). Following this idea, institutional arrangements, particularly combinations of rules, are needed to ensure effective management and avoid resource depletion and deterioration (Ostrom 1990, 2009; Agrawal 2002). As noted above in the Central America research, the principle concern has been with how collective institutions for resource management emerge (Tucker et al. 2007; Gibson 2001; McCay 2002; Johnson 2004). If forest conditions are the product of rational choices, then a positive perception of outcomes, through the evaluation of costs and benefits, becomes a clear incentive for cooperation and collective action leading to governance rules (Agrawal 2002; Ostrom 1990, 2009).

Ostrom's "design principles" are aimed at identifying key variables required to encourage collective action. Yet Van Laerhoven and Ostrom (2007: 11) self-critically write that research on the commons has a limited focus on institutional design rather than institutional change. When change is studied, it is assumed that all change in behavior occurs through changes in institutions (McCay, 2002). Peters (1987) argues, however, that the central question is to understand competing rights and claims around resources as well as human behavior as embedded in social systems. That is, rather than focusing on how and when people undertake collective action to design rules for better resource use, the larger issue is understanding the "causes and consequences of particular human-environment situations” (McCay 2002: 367).

This leads to the second issue. The methods used in traditional commons research have two prevailing characteristics: methodological individualism and theory driven, deductive models of inquiry (Johnson 2004; McCay 2002). The former leads to an overemphasis on individual rational choice, which, among other things, fails to recognize the myriad ways in which those choices are shaped by history and culture, how they may not be "rational", or how they may be based on other factors largely unrelated to the maintenance of the resource base (Johnson 2004; McCay 2002). The latter is related to the first 
problem above, whereby the set of questions - and thus what researchers find - is limited. For example, "well-defined boundaries" is one of the key variables identified for the success of common property resource management (Gibson et al. 2005; Ostrom 2009). In one of the few studies of the commons in Central America that takes a less traditional approach, Finley-Brook and Offen (2009) point out that "common-property analysis usually addresses locations where land plots have already been bound and thus focuses on resource rights and institutional decision-making within these pre-defined areas." Their study focuses on how diverse claims over indigenous territories in Nicaragua are represented, highlighting the importance of understanding the process of "bounding the commons" -specifically, the political and economic relations of inequality that shape the process and outcomes.

Assumptions behind the traditional commons approach leads to an absence of attention to power or politics; this constitutes a third issue limiting commons research. Peters (1987) and McCay (2002) argue that "the problem" assumed by commons scholars is the absence of social ties between the individual and others, when in fact the problem is competing rights and claims. Similarly, Johnson (2004) argues that there is an assumption that the rules that emerge from social ties are good for all - equitable and based on a moral economy rather than power and struggle. Agrawal (2003: 244) refers to the conceptual problem of "the idea of a sovereign, self-governing self and systems of property that stand above politics." The cases discussed below demonstrate the role of politics and competition at all levels.

Finally, and related to the previous issues, is the failure to take external context seriously (Goldman 1998; McCay 2002); Agrawal (2007: 124) writes that "variables related to the external environment... [constitute] the context within which the objects of interest for forest commons scholars - the configuration of common property arrangement, common pool resource, and user group - are located." According to Agrawal, despite these issues receiving more attention recently among scholars of forest commons, "they have often been identified as less important than institutional factors" (2007: 124). He argues, however, that markets and other external factors are "extremely important structuring variables" and yet commons scholars tend to find that they are not as important as scholars who look at causes of deforestation more specifically (Agrawal 2002, 2007). He calls this an "intriguing disjuncture" (Agrawal 2007: 124). The problem may be related to the use of overly deductive research models, discussed above. Further, even the idea that communities and institutions are "located" in a particular context is challenged by the case studies presented below. Rather, the commons presented here are dynamically produced. The commons scholar's unit of analysis is, in fact, a social construction in process and in constant flux. 


\section{The Case Studies}

The research presented here is based on a global comparative study of forest tenure reforms in 11 countries from 2006 to 2009 (Larson et al. 2010a and b). The research aimed to understand the nature of forest tenure reforms and the extent to which local rights had increased or were more secure in practice. ${ }^{2}$ This study, therefore, was not undertaken for the purposes of understanding the questions raised in this article; rather, the research findings from that project are used here to reflect on those questions.

Three research sites were selected in Central America: the North Atlantic Autonomous Region (RAAN) of Nicaragua, the Mayan Biosphere Reserve of the Northern Petén, Guatemala and the Guatemalan western highlands (Larson et al. 2008). Together, these three regions represent a wide variety of common property regimes and three very different types and contexts of reform ${ }^{3}$.

The research took a highly contextualized and nested approach. At the regional level, extensive literature reviews and key informant interviews were conducted to characterize the spectrum of land and forest tenure regimes, forest and land-use change and competing interests, particularly over forest resources. Based on these findings, communities or groups of communities representing different tenure arrangements were selected for in-depth research (Table 1). Depending on the nature of the organization managing the communal forest, the research focused at the level of a territory or group of communities, an association or enterprise, or the community.

The research questions most relevant to the issues addressed in this article are the following: How did reforms emerge and how were they implemented? ${ }^{4}$ How were land and forest tenure rights distributed before and after reform? How was the community organized to manage the commons and/ or to fight for reform? What were the obstacles to reform? At the local level, methods included dozens of semi-structured key informant interviews, focus groups and participant observation. The results have been published elsewhere (Larson and Mendoza-Lewis 2009, 2012; Monterroso and Barry 2012, 2010; Larson 2010; Larson et al. 2008, 2010a, b).

A comparative study of tenure reforms in these three emblematic regions provides an opportunity to examine very different types of forest commons under a single lens (Table 2). The cases each begin with a brief introduction, a discussion of the nature and emergence of the commons, and current dynamics and challenges. 


\begin{tabular}{|c|c|c|c|c|c|c|}
\hline Community & $\begin{array}{c}\text { Formal land } \\
\text { owner }\end{array}$ & Land user(s) & $\begin{array}{l}\text { Origen of formal } \\
\text { forest rights }\end{array}$ & $\begin{array}{c}\text { Forest user } \\
\text { organization }\end{array}$ & $\begin{array}{l}\text { Forest rule- } \\
\text { maker(s) }\end{array}$ & Type of forest \\
\hline \multicolumn{7}{|c|}{ North Atlantic Autonomous Region, Nicaragua } \\
\hline Layasiksa & $\begin{array}{l}\text { Undefined } \\
\text { (indigenous } \\
\text { communal rights } \\
\text { protected by law, } \\
\text { not yet titled) }\end{array}$ & $\begin{array}{l}\text { Indigenous } \\
\text { community (divided in } \\
\text { two villages), family } \\
\text { agricultural areas, } \\
\text { common forest and } \\
\text { pasture }\end{array}$ & $\begin{array}{l}\text { Indigenous } \\
\text { communal rights } \\
\text { protected by law } \\
\text { and Constitution }\end{array}$ & $\begin{array}{l}\text { Community - } \\
\text { formal enterprise, } \\
\text { open to all }\end{array}$ & $\begin{array}{l}\text { Community \& } \\
\text { enterprise } \\
\text { organization \& } \\
\text { traditional } \\
\text { sindico (subject } \\
\text { to state } \\
\text { regulation) }\end{array}$ & $\begin{array}{l}\text { Lowland tropical } \\
\text { broadleaf and } \\
\text { pine }\end{array}$ \\
\hline Tasba Raya & $\begin{array}{l}\text { Individual titles } \\
\text { and title for } \\
\text { Tasba Raya } \\
\text { Wanki Twi } \\
\text { territory }\end{array}$ & $\begin{array}{l}\text { Indigenous } \\
\text { communities (six } \\
\text { villages), individual } \\
\text { areas and common } \\
\text { forest }\end{array}$ & $\begin{array}{l}\text { Individual titles } \\
\text { and collective title }\end{array}$ & $\begin{array}{l}\text { Community (from } \\
\text { six villages) - no } \\
\text { specific forest } \\
\text { organization }\end{array}$ & $\begin{array}{l}\text { Community } \\
\text { through } \\
\text { traditional } \\
\text { sindico (subject } \\
\text { to state } \\
\text { regulation) }\end{array}$ & $\begin{array}{l}\text { Lowland tropical } \\
\text { broadleaf }\end{array}$ \\
\hline \multicolumn{7}{|c|}{ Maya Biosphere Reserve, Petén, Guatemala } \\
\hline Carmelita & $\begin{array}{l}\text { State-protected } \\
\text { area }\end{array}$ & $\begin{array}{l}\text { Community lives in } \\
\text { forest since } 1920 \text {, } \\
\text { individual agricultural } \\
\text { areas, common forest }\end{array}$ & $\begin{array}{l}\text { Concession } \\
\text { contract }\end{array}$ & \begin{tabular}{|l|} 
Concession \\
organization \\
within \\
community, open \\
to all \\
\end{tabular} & $\begin{array}{l}\text { State } \\
\text { (Protected } \\
\text { Areas Council } \\
\text { CONAP) }\end{array}$ & $\begin{array}{l}\text { Lowland tropical } \\
\text { broadleaf }\end{array}$ \\
\hline Arbol Verde & $\begin{array}{l}\text { State-protected } \\
\text { area }\end{array}$ & $\begin{array}{l}\text { Concession } \\
\text { organization, common } \\
\text { forest }\end{array}$ & $\begin{array}{l}\text { Concession } \\
\text { contract }\end{array}$ & \begin{tabular}{|l|} 
Concession \\
organization \\
made up of \\
individuals from \\
several \\
communities, \\
shareholders must \\
buy in \\
\end{tabular} & $\begin{array}{l}\text { State } \\
\text { (Protected } \\
\text { Areas Council } \\
\text { CONAP) }\end{array}$ & $\begin{array}{l}\text { Lowland tropical } \\
\text { broadleaf }\end{array}$ \\
\hline \multicolumn{7}{|c|}{ Western Higblands, Guatemala } \\
\hline Mogotillos & $\begin{array}{l}\text { Municipality } \\
\text { (ejido) }\end{array}$ & $\begin{array}{l}\text { Community, } \\
\text { individual areas, } \\
\text { common forest } \\
\text { (community protected } \\
\text { area) }\end{array}$ & $\begin{array}{l}\text { Forest area } \\
\text { granted to } \\
\text { community by } \\
\text { municipal } \\
\text { agreement }\end{array}$ & $\begin{array}{l}\text { Community - no } \\
\text { specific forest } \\
\text { organization }\end{array}$ & $\begin{array}{l}\text { Community } \\
\text { (based on } \\
\text { municipal } \\
\text { agreement) }\end{array}$ & Highland pine \\
\hline Chichim & $\begin{array}{l}\text { Municipality } \\
\text { (ejido) }\end{array}$ & $\begin{array}{l}\text { Indigenous } \\
\text { community, individual } \\
\text { areas, common forest }\end{array}$ & $\begin{array}{l}\text { Municipality } \\
\text { establishes rules }\end{array}$ & Community & $\begin{array}{l}\text { Community as } \\
\text { granted and } \\
\text { limited by } \\
\text { municipality }\end{array}$ & Highland pine \\
\hline Estancia & $\begin{array}{l}\text { Municipality } \\
\text { (ejido) }\end{array}$ & $\begin{array}{l}\text { Community, } \\
\text { individual areas, } \\
\text { common forest }\end{array}$ & $\begin{array}{l}\text { Community } \\
\text { demanded right to } \\
\text { family's } \\
\text { abandoned land } \\
\text { with regenerated } \\
\text { forest }\end{array}$ & $\begin{array}{l}\text { Forest } \\
\text { organization and } \\
\text { community }\end{array}$ & $\begin{array}{l}\text { Community's } \\
\text { forest } \\
\text { committee and } \\
\text { community } \\
\text { (subject to state } \\
\text { regulation) }\end{array}$ & Highland pine \\
\hline Chancol & $\begin{array}{l}\text { Group of } 504 \\
\text { associates with } \\
\text { board of } \\
\text { directors }\end{array}$ & $\begin{array}{l}\text { Community (in } 13 \\
\text { villages), all area } \\
\text { divided among } \\
\text { families except for } \\
\text { small common area } \\
\text { with lake (community } \\
\text { protected area) }\end{array}$ & Collective title & $\begin{array}{l}\text { Community/ } \\
\text { households }\end{array}$ & $\begin{array}{l}\text { General } \\
\text { assembly of } \\
\text { community and } \\
\text { forest } \\
\text { organization } \\
\text { (subject to state } \\
\text { regulation) }\end{array}$ & Highland pine \\
\hline
\end{tabular}

Table 1. Some characteristics of commons in the case study communities 


\begin{tabular}{|c|c|c|c|c|c|c|c|c|}
\hline Cases & $\begin{array}{l}\text { Formal } \\
\text { ownership } \\
\text { (title holder) }\end{array}$ & $\begin{array}{l}\text { Nature of } \\
\text { community } \\
\text { rights over } \\
\text { forest }\end{array}$ & $\begin{array}{l}\text { Common } \\
\text { forest? }\end{array}$ & $\begin{array}{l}\text { Role of the collective } \\
\text { in forests (common } \\
\text { and individual) }\end{array}$ & $\begin{array}{l}\text { Role of the } \\
\text { state in forests }\end{array}$ & $\begin{array}{l}\text { Length of } \\
\text { time forest } \\
\text { rights } \\
\text { granted }\end{array}$ & $\begin{array}{l}\text { Security of } \\
\text { legal } \\
\text { instrument } \\
\text { granting } \\
\text { forest rights }\end{array}$ & $\begin{array}{l}\text { Security in } \\
\text { practice/ threats }\end{array}$ \\
\hline Layasiksa & Not yet titled & $\begin{array}{l}\text { All but } \\
\text { alienation rights }\end{array}$ & Yes & $\begin{array}{l}\text { Makes rules for all } \\
\text { forest; forest } \\
\text { management } \\
\text { enterprise }\end{array}$ & Regulator & In perpetuity & $\begin{array}{l}\text { Secure, but } \\
\text { not yet titled }\end{array}$ & $\begin{array}{l}\text { Specific area not } \\
\text { yet defined }\end{array}$ \\
\hline Tasba Raya & $\begin{array}{l}\text { Inside larger } \\
\text { titled territory; } \\
\text { individual } \\
\text { titles }\end{array}$ & $\begin{array}{l}\text { All but } \\
\text { alienation rights }\end{array}$ & Yes & $\begin{array}{l}\text { Makes rules for all } \\
\text { forest but mainly } \\
\text { common forest }\end{array}$ & $\begin{array}{l}\text { Regulator; may } \\
\text { grant } \\
\text { concessions } \\
\text { w/community } \\
\text { permission }\end{array}$ & In perpetuity & Secure & $\begin{array}{l}\text { Area titled but } \\
\text { claims inside } \\
\text { borders not yet } \\
\text { resolved }\end{array}$ \\
\hline Carmelita & State & $\begin{array}{l}\text { Management } \\
\text { subject to } \\
\text { concession } \\
\text { rules }\end{array}$ & Yes & $\begin{array}{l}\text { Forest management } \\
\text { enterprise }\end{array}$ & $\begin{array}{l}\text { Owner, rule } \\
\text { maker }\end{array}$ & 25 years & Secure & $\begin{array}{l}\text { Competing claims, } \\
\text { pressures to end } \\
\text { concession }\end{array}$ \\
\hline Arbol Verde & State & $\begin{array}{l}\text { Management } \\
\text { subject to } \\
\text { concession } \\
\text { rules }\end{array}$ & Yes & $\begin{array}{l}\text { Forest management } \\
\text { enterprise }\end{array}$ & $\begin{array}{l}\text { Owner, rule } \\
\text { maker }\end{array}$ & 25 years & Secure & $\begin{array}{l}\text { Illegal logging, } \\
\text { secure given } \\
\text { natural limits }\end{array}$ \\
\hline Mogotillos & $\begin{array}{l}\text { Municipal } \\
\text { government }\end{array}$ & $\begin{array}{l}\text { All but } \\
\text { alienation rights }\end{array}$ & Yes & $\begin{array}{l}\text { Makes rules over } \\
\text { common forest }\end{array}$ & Owner, regulator & In perpetuity & Insecure & $\begin{array}{l}\text { Secure if } \\
\text { community is } \\
\text { belligerent }\end{array}$ \\
\hline Chichim & $\begin{array}{l}\text { Municipal } \\
\text { government }\end{array}$ & $\begin{array}{l}\text { Management, } \\
\text { Exclusion } \\
\text { subject to } \\
\text { municipal rules }\end{array}$ & Yes & $\begin{array}{l}\text { Makes some rules over } \\
\text { common forest }\end{array}$ & $\begin{array}{l}\text { Owner, rule } \\
\text { maker }\end{array}$ & $\begin{array}{l}\text { Decision of } \\
\text { the municipal } \\
\text { government }\end{array}$ & $\mathrm{NA}$ & $\begin{array}{l}\text { Protected area } \\
\text { declaration limits } \\
\text { rights }\end{array}$ \\
\hline Estancia & $\begin{array}{l}\text { Municipal } \\
\text { government }\end{array}$ & In negotiation & $\begin{array}{l}\text { Only small } \\
\text { area }\end{array}$ & $\begin{array}{l}\text { Makes rules for all } \\
\text { forest (including } \\
\text { individual lands) }\end{array}$ & Regulator & $\mathrm{NA}$ & $\mathrm{NA}$ & In negotiation \\
\hline Chancol & $\begin{array}{l}\text { Group of } \\
\text { owners }\end{array}$ & $\begin{array}{l}\text { Full ownership, } \\
\text { including } \\
\text { alienation }\end{array}$ & $\begin{array}{l}\text { Only small } \\
\text { area }\end{array}$ & $\begin{array}{l}\text { Makes rules for all } \\
\text { forest (including } \\
\text { individual lands) }\end{array}$ & Regulator & In perpetuity & Secure & $\begin{array}{l}\text { Secure, potential } \\
\text { change to rights if } \\
\text { protected area } \\
\text { enacted }\end{array}$ \\
\hline
\end{tabular}

Table 2. Nature and Security of Rights

\section{North Atlantic Autonomous Region (RAAN), Nicaragua}

Peace negotiations with indigenous leaders after several years of war led to the recognition of indigenous communal land rights in the Nicaraguan national constitution of 1987 and the establishment of two autonomous regions $^{5}$ in the north and south Atlantic coast (Hale 1996; Ortiz 1987). In 2003, the Communal Lands Law ${ }^{6}$ established the institutional framework for demarcation and titling, and in 2007 indigenous leaders actively promoted the formation of large indigenous territories under a supportive central government administration. Several of those territories are now titled. The community-level research focused on two groups of Miskitu communities, one with individual land titles and some untitled common forest (Tasba Raya), the other with only untitled common land (Layasiksa); neither had territory titles at the time of the study. These cases represent two examples of many kinds of problems faced in the implementation of reforms (see Larson and Soto 2012 for additional cases).

\section{Nature and Origin of the Commons}

Indigenous leaders argue that their ancestral land rights pre-date the Nicaraguan state. Few communities have had land titles, however, with which to 
guarantee their claims before the law, the state and outside intruders. Even after the state recognized indigenous rights to their cultural identity, forms of organization and property in the 1987 Constitution, rights in practice saw little change, as the state continued to grant resource concessions on communal lands. This did not stop until several years later, after the community of Awas Tingni filed a case against the Nicaraguan state before the Inter-American Court for Human Rights (Corte Interamericana de Derechos Humanos-CIDH). Nicaragua lost the case and was ordered to create an effective mechanism for demarcation and titling for indigenous communities (Anaya and Grossman 2002). One result, among other things, was the Communal Lands Law, which went into effect in 2003. It was not until several years later, however, with a change of government administration that a serious effort at land demarcation and titling was made.

In the two communities studied, both had previously existing titles but only to a part of their land. Tasba Raya consists of a group of seven communities that had been voluntarily resettled from lands near the Honduran border in the 1960s. Each settlement, designed by the Nicaraguan Agrarian Institute (IAN), was laid out in a grid as a bloc of agricultural lands that were assigned and titled to individual families, and a separate communal area was designated for housing. Though IAN did not formally assign (with title) other communal lands, residents claim that they were given free use of a forest area adjacent to their titled lands, which they identify by specific landmarks. They have used this area as communal land both for common use, especially for hunting and forest products, and for the assignation of new lands to growing families and new community members. Today this area is managed through an elected sindico - the authority normally in charge of land and resource allocation (Larson and Mendoza-Lewis 2009).

Layasiksa is a much older community than Tasba Raya, with title to only a small portion of its area (2,060 ha) granted in 1917. Layasiksa consists of two communities, one that was founded in 1998 when a small group of residents moved into an area of broadleaf forest to take advantage of these resources as a new source of income. Though there were apparently rules about forest use prior to this time (Soto 2007), the community only began to manage it effectively as common property once it asserted its land claim (resulting in an end to two commercial logging concessions associated with other communities) and developed a plan for land and forest management with the support of the World Wildlife Fund (WWF). This includes a commercial community logging enterprise.

\section{Dynamics of the Commons: Negotiating Boundaries}

The indigenous communities of the RAAN have held common forests either as open access or managed resources undoubtedly for as long as there have been indigenous people in the region. It was not until recently, however, that they were granted the formal right to exclude outsiders, including the state, and to obtain land titles to large areas of forest commons. What this has meant in practice is a dynamic reconfiguration of the commons in the context of the 
formation of indigenous territories for demarcation and titling (Larson 2010). The configuration of territories has direct implications for the management of common forests, because elected territorial authorities play a central role in granting access to forests by outsiders, such as logging concessions.

Though the Communal Lands law states that communities should be titled as they propose, individually or as multi-community territories, political leaders from the Miskitu political party Yatama pushed communities to form territories based on the design that they had conceived. Among other things, Miskitu leaders were interested in reshaping electoral districts to strengthen regional autonomy: eliminating the municipal structure imposed by the central government and replacing it with an "indigenous" structure of territories and territorial authorities (see Larson and Mendoza-Lewis 2009, 2012 for more detail).

Tasba Raya had a different proposal. Leaders argued that their seven communities had a natural affinity based on their common history and forms of land tenure, close proximity and familial ties and the development of common governance systems for access to and use of resources in shared areas. But Yatama political leaders insisted the communities of Tasba Raya join with a much larger area with a total of 23 communities. After extensive pressure and negotiation, Tasba Raya's leaders accepted and the 23-community territory of Wangki Twi-Tasba Raya was titled in June 2010.

Layasiksa has had a similar experience. Layasiksa did not refer to its two communities as a territory or organize as such until 2008, after the fieldwork upon which this article is based was completed. In 2007, community leaders obtained a grant from the United Kingdom's Department for International Development (DFID) to carry out the diagnostic studies and demarcation of its claim, calling the territory Prinzu Rau and negotiating borders with their neighbors. Nevertheless, it was not able to gain formal recognition of this territory by regional political leaders and, like Tasba Raya, has been included inside another (not yet titled) territory.

\section{The Mayan Biosphere Reserve, Northern Petén, Guatemala}

In the Petén, Guatemala, the Maya Biosphere Reserve (MBR) was created in 1990 to protect biodiversity along the northern border with Mexico (Radachowsky 2012). Encompassing over two million ha, the reserve's master plan created three management zones. Over 40 percent of the reserve, the Multiple Use Zone (MUZ), permits sustainable use, including logging, and a number of concessions were granted to industries and communities living in and around the area. Before the establishment of the protected area, a few communities already lived inside the forest, while others lived in more urban areas. The community-level research focused on one of each, Carmelita and Arbol Verde.

\section{Nature and Origin of the Commons}

In 1994, the government, with strong backing of international donors, legalized a formal community concession system within the MUZ (Rada- 
chowsky et al. 2012; Monterroso and Barry 2012; Taylor 2009). The purpose was to recognize the historic and recent settlement rights of existing communities and at the same time support the forest conservation agenda, while not entirely alienating the industrial timber sector. Community access and settlement rights were recognized, and the rights to manage and sell timber and non-timber forest resources were conferred on the basis of a heavily regulated scheme of independent, certified production of high-value timber species, transforming the previously conflictive forest landscape. Between 1994 and 2001, a total of twelve community concessions contracts (for areas ranging from 7,000 ha to $85,000 \mathrm{ha}$ ) were signed with organized resident and non-resident local community groups (a total of 390,000 ha) (Radachowsky et al. 2012; Monterroso and Barry 2012). A community concession represents a 25 -year contract between an organized and legally recognized group and the Guatemalan government, which grants usufruct rights to the former to manage renewable resources in protected areas. The state holds alienation rights as well as usufruct rights over non-renewable resources.

\section{Dynamics of the Commons: Ongoing Threats}

All concession contracts require collective organization and resource extraction based on management plans approved by the National Council of Protected Areas (CONAP). Over the past 10-15 years, the community organizations have been able to build their own local governance systems, based on an expanded set of rights of access, use and decision-making over their natural resources. This includes organizing and financing the constant protection of the boundaries of the concessions as part of their responsibilities (Ibid.).

Nevertheless, threats to the concessions are ongoing and varied, requiring continuous vigilance in a number of different arenas. With regard to encroachment and poaching, most of the concession organizations have been able to stabilize these activities, though not without considerable investment. A few concessions, however, and particularly those with histories of recent establishment and greater proximity to the agricultural frontier, are much more vulnerable (Radachowsky et al. 2012; Bray et al. 2008).

Farmers and ranchers, however, are not the most significant threat. Current renewed interests in the control of resources in the Petén have emerged from a variety of different development interests, particularly tourism and petroleum. The creation of a second-order organization, the Association of Forest Communities of Petén (ACOFOP) in 1995 has been key to the success of community-based forestry in the region, particularly in light of these threats (Taylor 2009 and 2012). Initially ACOFOP played a crucial role as political advocate in broadening the bundle of rights over common forests in favor of communities in the MUZ (Paudel et al. 2010). Since then, ACOFOP has represented the concessions at the national and international level and become a central interlocutor between the state and the communities.

Threats from development interests have placed the concession organizations at odds with both private interests and actors within the state apparatus 
who question the benefits of the community concession system in comparison to broader development goals. One example is the proposal for the expansion of the Mirador Basin project. The Mirador-Río Azul National Park is located in the MBR and covers about $82 \mathrm{~km}^{2}$. In 2002, Presidential Decree 129-2002 expanded the park to $2,124 \mathrm{~km}^{2}$, in response to lobbying by private and nongovernmental organizations, which argued that the existing area was not large enough to protect the park's archaeological site (GHF and FARES 2006, see also http://www.miradorbasin.com). ACOFOP mobilized about 5,000 community members over two and a half years with a total investment of about US $\$ 130,000$ to fight this. Though the decision was revoked in 2005, a new bill (Initiative 4234) appeared in the Guatemalan congress again in 2009. Like the former, the proposal fails to recognize existing rights and affects recently recognized rights in the concessions (Monterroso 2007; Taylor 2010).

\section{Western highlands, Guatemala}

There are hundreds of communal forests in the Guatemalan highlands, known under a variety of official land tenure types, particularly municipal lands (ejidos) and numerous joint ownership arrangements (Grupo Promotor 2009; Thillet et al. 2003; Elías 2010). The 2005 Law for the Registry of Cadastral Information (Registro de Información Catastral - RIC) recognized communal lands in national law for the first time; it specifically established that communal lands "are lands in property, possession or tenure of indigenous and peasant communities as collective entities, with or without legal standing. In addition, those lands that are registered in the name of the state or municipal governments, but that have been traditionally possessed or held communally, form part of these lands" (Article 23). The research included four communities, three of which held forests legally under municipal tenure, but with substantial variety in what this meant in practice, and one that held a collective title.

\section{Nature and Origins of the Commons}

The population of the western highlands is 80 percent indigenous (INE 2002). The land tenure systems found there today are the result of hundreds of years of history, characterized in the colonial and post-colonial eras predominantly by the usurpation of indigenous lands by more powerful actors (Cambranes 2004; Elías et al. 2009). The liberal governments of the $19^{\text {th }}$ century were expressly interested in suppressing communal land tenure, and many indigenous communities were forced to sell or rent their land to private farmers or to transfer their rights to municipal governments (Elías et al. 2009; Gliejeses 1989). Beginning in the 1950s, over three decades of a brutal war weakened community organizations, and the abandonment of villages facilitated the usurpation of land (Lartigue 1993). Since then, in spite of peace accords and the state's commitment to reverse this history of land pillage, little has been done to restore or strengthen communal tenure rights (Bastos and Camus 2003; Elías et al. 2009). 
The result today is a highly varied land structure that includes forests managed by communities under multiple of legal forms. The four sites studied demonstrate four different ways in which communities have obtained and manage commons (see Table 1 for more details). Chancol is a large farm encompassing 15,000 ha that was titled in 1955 in the name of 504 associates, who were the original owners. In 1991, the community made the decision to distribute the land equally among the founding families in order to return to a more equitable distribution. The title remains collective and is held by a board of directors that is elected every two years, and overarching land and resource management norms and rules are still made collectively (Elías et al. 2009).

Mogotillos and Estancia la Virgen are both located on municipal lands, but these are occupied by individual proprietors with alienation rights to their parcels. Mogotillos fought and won the municipal government's formal recognition of its rights over a 50-ha forest that had historically been communal. It now has all tenure rights to that forest, except the right to sell it, but legally the Mayor could reverse this decision at any time. Since 1992, Estancia la Virgen had been managing a 56-ha area, abandoned by its proprietor, as a communal forest. A forest committee was formed to establish community control and rules for the use of the abandoned area. At the time of the study, community leaders were fighting for permanent rights to the area, as a man had recently appeared claiming to be the legal heir (Mendoza 2007).

Finally, Chichim - the only fully indigenous community in the study - is also located on municipal lands and has a communal forest that is formally municipal. It is subject to the decisions of the municipal government regarding the forest, which has currently granted rights to access, withdrawal, management and exclusion. Chichim does not have alienation rights and explicitly does not have the right to commercial use of any forest resources (Ibid.).

\section{Dynamics of the Commons: Conservation Pressures}

Though indigenous and peasant communities rarely have the required legal documents, Article 65 of the RIC law establishes that "If communal ownership, possession or tenure of lands is determined during the process of cadastral establishment, the RIC shall recognise and make the administrative declaration of communal land and issue the certifications." Nevertheless, communities are often not aware of this provision, nor are such legal provisions, in and of themselves, "sufficient to ensure collective rights to communal lands" (Elías 2010).

Communal forests in the highlands are being subject to a variety of pressures, particularly from external actors. Municipal governments and national and foreign investors are interested in developing mining, hydroelectric and infrastructure projects in the region. The research focused more on conservation actors, both conservation $\mathrm{NGOs}^{7}$ and CONAP, which have taken a particular interest in the remaining highland forests for the generation of water resources and the protection of important endemic species. Because firewood collection and sheep farming are blamed as the primary causes of forest degradation, con- 
servationists have tried to restrict these activities, although the evidence underlying their claims has been questioned (Elías et al. 2009). In 1997, the government restricted the sale and use of pinabete (Abies guatemalensis Rehder), a highland pine species popular for Christmas trees, other ornamental uses and carpentry. Several protected areas have been declared or are in the process of being decreed; the goal is to create a series of interconnecting corridors by including a number of municipal and communal forests, at least one of which is included in the case studies (Chichim).

Though highland communities have sometimes seen conservation NGOs as allies, there are also conflicts. In fact, restrictions on pinabete, firewood use and sheep farming may affect the poorest rural families most, forcing them to bear the costs of protection without offering alternatives or compensation in return (Elías 1997). Projects are developed with ecological motivations that are not concerned with guaranteeing the long-term supply of firewood and timber. In some cases, conservation NGOs have approached the formal municipal owners of forests but not the communities that claim them. In Chichim, the declaration of a protected area led to restrictions on use, divisions in the community and fear that the community would lose control over the land. In response, community members began appropriating forest land illegally. At the time of the study, Mogotillos was considering declaring its communal forest as a protected area but was also concerned that this might affect their future rights. Chancol was inside an area declared as protected, but this had not yet been implemented (Elías et al. 2009).

\section{Understanding Central American Forest Commons}

A traditional common property approach to the cases discussed here would not permit scholars to understand the full range of factors affecting the motivations and behavior of local people, including their incentives for collective action and the meaning and use of forests, competing claims to resources or the potential and challenges for the future of the forest and local livelihoods. All of these are deeply socially and historically embedded in the processes of formation of the commons and the ongoing collective - and conflictive - construction of boundaries, rights and rules. The cases demonstrate that resource governance institutions are deeply embedded in social, cultural and political processes that go far beyond rules for resource use (Larson and Lewis-Mendoza 2012). Though there is wide variation in terms of the origin of land claims, the type of claimants, the type of forests, the extent to and means by which the state has recognized these claims to forest commons, the cases presented here all have this in common. Three specific arenas of inquiry are proposed.

\section{History and Change Over Time}

Understanding how collectives create and recreate institutions through time - and the variables that influence institutional change and the nature of collective action - is key to understanding resource management and outcomes. Common property research based on the International Forestry Resources and 
Institutions (IFRI) protocols is designed to allow case study locations to be revisited regularly (Clark 2001), but deeper historical analysis is required (Agrawal 2003, 2005). Peters (1987) provides an excellent example. McCay (2002) proposes a variety of specific methods to move beyond methodological individualism and capture social and historical embeddedness of action.

In our research, while some of the cases analyzed are the result of recent forest tenure reforms, all of them are the product of historical processes of negotiation and conflict. For instance, while the longest community concession contract in the Petén is barely over fifteen years old, the concession system cannot be explained without analyzing the establishment of the MBR in the 1990s (Monterroso and Barry 2012). In fact, the creation of the MBR in Petén responds to a series of territorialization strategies promoted by the Guatemalan state to gain authority in this agricultural frontier hinterland starting with the establishment of forest concessions in the 1970s.

Additionally, the titling of indigenous territories in Nicaraguan Atlantic Coast cannot be fully understood without analyzing the relationship of the Caribbean Coast to the rest of the Nicaraguan territory over the last hundred years. Although the titling of territories is a recent phenomenon, with some titles less than a year old, these processes are the result of long-term negotiation and conflict between the indigenous peoples and the Nicaraguan state. Finally, in the Guatemalan highlands, while conservation actors and municipal authorities are recent stakeholders in communal forests, the history of dispossession of communities' forest resources and land has colonial roots.

\section{Multiple Actors at Multiple Scales}

To date, common property research in the region has generally focused on local case studies, thus lacking broader analyses into interlinked processes across multiple geo-political scales. The scale of analysis should not only be linked to the level at which direct resource management activities take place but rather to multiple levels, taking into account the multiple actors - including but not limited to the state - that make demands on resources and decisions affecting resource management.

The cases studied here demonstrate the dynamic interplay of placebased and issue-based communities; multi-community territories; local, regional and national governments; and NGO and private sector interests. There is a widespread coexistence of overlapping claims. For instance, there are overlaps between protected areas and communities in the Petén and in the Guatemalan highlands. There are overlapping claims between forest users and outside interests such as expansion of tourism in the MBR. Municipal and communal lands overlap in the highlands. These overlapping and often contradictory claims have implications for research, given that different collectivities may have rights over different resources within the same forest area at the same or different times. For communities these constitute significant challenges. 
The role of multiple layers of government is particularly important in all of our cases. In the highlands, forest resources and lands historically managed by local groups are often legally owned by municipal governments. Indigenous territorial governments in Nicaragua compete with municipalities for power and resources. Forestry institutes, protected area offices, regional and local governments compete to legitimate their authority before forest claimants. The analysis of forest commons in the region would benefit from political ecology approaches that explicitly take into account issues of power, politics and scale.

\section{Production of Space}

In common property research, institutions, including the boundaries of property, evolve, are designed, or are negotiated through straightforward, apolitical processes (Agrawal 2003, 2005; Johnson 2004; Finley-Brook and Offen 2009; Taylor 2009). Boundary definition is important as it facilitates the production of rules that restrict access and substractibility of products. However, research related to the production and reproduction of space (Lefebvre 1974; Harvey 1990) suggests that boundaries are often contested through time, as they are linked to the process of recognition of rights and claims. Similarly, Sack (1986) writes that the social construction of territory and exercise of control over a geographic space requires constant effort. The cases discussed here demonstrate that boundaries are produced through historically-grounded struggles and are constantly being contested. This is true not only of the physical boundaries of a territory, but also of political boundaries defining rights, powers and responsibilities.

In Nicaragua, the central issue is the definition of boundaries in the construction, or reconfiguration, of the commons (Larson and Mendoza-Lewis 2012). Though communities have been managing common property for decades, if not centuries, the specific rights granted have changed substantially in the past 25 years. And the precise boundaries of those common areas have recently shifted from the community to territory scale, with multiple, contested configurations.

In the Petén, the commons are being shaped by external competition over resources and boundaries. In this case, the precise borders of the concessions are defined by maps and in contracts, under apparently very secure legal mechanisms. Nevertheless, vulnerable concessions bordering the agricultural frontier are being eaten away at the edges (Radachowsky 2012), and competing interests for tourism and the expansion of the Mirador site threaten to reverse the rights altogether.

In the highlands, communal lands have been under threat for more than a century. New "public interest" in conservation -specifically, the expansion of protected areas in the remaining highland forests - threatens to limit community rights and, thus, reshape community institutions. Attention to the production of space and boundaries would be improved by the adoption of research approaches that are more question-driven and inductive (Johnson 2004; 
McCay 2002), moving beyond the conception of physical boundaries only as a geographic space to be "clarified" and their understanding contestation in the context of broader actors, interests and power relations.

\section{Conclusions}

This article uses the findings from research on three important regions of communal forests in Central America to argue that traditional common property research has considerable shortcomings that limit the potential to better understand the motivations and behavior of local people as they affect the region's forests. As argued by a number of commons scholars during the last twenty years (Peters 1987; Goldman 1998; McCay and Jentoft 1998; McCay 2002; Johnson 2004; Agrawal 2002, 2003, 2007; Armitage 2008), the majority of common property research is shaped by a limited and overly predetermined set of research questions, methods that fail to address the socially and historically embedded nature of individuals, an apolitical approach to community and the failure to recognize the centrality of "external context".

What is perhaps most interesting is that there has been only marginal change in approaches to common property scholarship in spite of the history of critique. Some changes include additional variables on the external context included in the design variables (Ostrom 2009), and Agrawal (2005), among others, has promoted greater attention to history and struggle in the production of institutions. There has been greater attention to the need to shift from a focus on apparently simple management systems to the recognition of commons governance "as a complex systems problem" (Armitage 2008: 15) and of multiple linkages through networks (Young 2002; Berkes 2002, 2010). Nevertheless, an accounting of articles using the words "complex" or "uncertain" in Van Laerhoven and Ostrom (2007) found only a small number in 2005 and 2006, though they appeared to be increasing. As Johnson (2004: 407) poignantly argues, the problem may lie in the "wider intellectual trend of positivism, methodological individualism and formal modeling that has come to dominate social science in the United States".

As demonstrated by the cases presented in this article, however, our understanding demands consideration of the political and historical processes that construct and shape forest tenure rights and practices, taking into account history and change over time, conflict and negotiation with multiple actors at multiple scales and the dynamic production of space and boundaries. Research is required that pays greater attention to the dynamic processes that produce and alter institutions and behavior, including not only the analysis of changing property rights but also broader processes of territory construction. These dynamic landscapes present considerable challenges not only for communities but also for practitioners. 


\section{Notes}

1 Agrawal (2003) refers to "most writings on common property". Johnson (2004) refers to a "mainstream" in common property writings, which he calls "collective action scholars", contrasting their approach to those he refers to as "entitlement scholars". In this article the term "traditional" is used in order to distinguish the majority of commons scholarship from a minority who have used or advocated for other approaches.

2 The sites selected represent places in which local people had won statutory rights to forests in recent years and where there were opportunities to support those statutory reforms.

${ }^{3}$ These three regions represent three of the five most important regions of common property forests in Central America. The others include the comarcas of Panama and the lowland tropical forests of Honduras.

${ }^{4}$ This included, but was not limited to, the bundle of rights defined in Schlager and Ostrom (1992): access (the right to enter the area), use or withdrawal (the right to obtain and remove resources from the forest), management (the right 'to regulate internal use patterns', Agrawal and Ostrom 2001: 489), exclusion (the right to decide who can and cannot use the resource) and alienation (the right to sell, transfer or lease the land and all of the previous rights).

${ }^{5}$ The autonomy statute created the institutional framework for the election of regional authorities and granted greater control to indigenous communities and traditional peoples over the autonomous regions and their natural resources (Autonomy Statute, Law no. 28).

${ }^{6}$ Law No. 445 of the Communal Property Regime of the Indigenous Peoples and Ethnic Communities of the Autonomous Regions of the Atlantic Coast of Nicaragua and of the Bocay, Coco, Indio and Maiz Rivers, referred to here as the Communal Lands Law.

${ }^{7}$ A consortium of NGOs formed to promote the declaration of protected areas in the Western Highlands. For more information, see Elias et al. 2009; Elias 2012.

\section{References}

Agrawal, A. 2007. Forest, governance and sustainability: Common property theory and its contributions. International Journal of the Commons 1(1): 111-136.

2005. Environmentality: Technologies of Government and the Making of Subjects. Durham: Duke Univ. Press. 
2003. Sustainable Governance of Common-Pool Resources: Context Methods and Politics. Annual Review of Anthropology 32: 243-262.

2002. Common Resources and Institutional Sustainability. In The Drama of the Commons. National Resource Council (Eds.), pp. 41-86. Washington, D.C.: The National Academy Press.

ANAM. 2009. Informe sobre los Criterios e Indicadores de la OIMT para la Ordenación Sostenible de los Bosques Tropicales. Formatos con respuestas para la actualización del progreso alcanzado por Panamá desde 2004 a 2008 en materia de ordenación forestal. Autoridad Nacional del Ambiente. Septiembre 2009. Unpublished.

Anaya, S. J. and Grossman, C. 2002. The Case of Awas Tingni v. Nicaragua: a New Step in the International Law of Indigenous Peoples. Arizona Journal of International and Comparative Law 19(1): 1-15.

Armitage, K. 2008. Governance and the Commons in a Multi-Level World. International Journal of the Commons 2(1): 7-32.

Bastos, S. and M. Camus. 2003. 10 años de lucha por la Madre Tierra, la vida y la paz. Guatemala: CONIC.

Berkes, F. 2010. Devolution of Environment and Resources Governance: Trends and Future. Environmental Conservation 37(4): 489-500.

2002. Cross-Scale Institutional Linkages: Perspectives from the Bottom Up. In The Drama of the Commons, National Resource Council (Eds.), pp. 293-321. Washington, D.C.: National Academy Press.

Bray, D. B., E. Duran, V. H. Ramos, J-F. Mas, A. Velazquez, R. B. McNab, D. Barry and J. Radachowsky, J. 2008. Tropical Deforestation, Community Forests, and Protected Areas in the Maya Forest. Ecology and Society 13(2), article 56.

Cambranes, J. C. 2004. 500 años de lucha por la tierra. Guatemala: Cholsamaj.

Chhatre, A. 2008. Communities, institutions and institutional trajectories. The Commons Digest No. 6, summer, pp. 10-11.

De Janvry, A. 1989. The Agrarian Question and Reformism in Latin America. Baltimore: Johns Hopkins Press.

Elías, S. 2010. De bosques comunales a áreas protegidas: las implicaciones de los cambios de tenencia en la gestión colectiva de recursos naturales en Guatemala. Mimeo. 
1997. Autogestión comunitaria de recursos naturales. Estudio de caso en Totonicapán. Guatemala: FLACSO Editorial.

Elías, S., A., M. Larson and J. Mendoza. 2009. Tenencia de la tierra, bosques y medios de vida en el Altiplano Occidental de Guatemala. Guatemala: CIFOR.

Enriquez, L. 1991. Harvesting Change: Labor and Agrarian Reform in Nicaragua, 1979-1990. Chapel Hill: University of North Carolina Press.

Eickstein, S. 2001. Power and Popular Protests. Latin American Social Movements. Berkeley: University of California Press.

Finley-Brook, M. and K. Offen. 2009. Bounding the Commons: Land Demarcation in Northeastern Nicaragua. Bulletin of Latin American Research 28(3): 343363.

Gauster and Isakson, 2007. Eliminating Market Distortions, Perpetuating Rural Inequality: An Evaluation of Market-Assisted Land Reform in Guatemala. Third World Quaterly 28(8): 1519-1536.

GHF (Global Heritage Fund) and FARES. 2006. Mirador conservation proposal: Establishing a 525,100 acre archeological and wilderness preserve in the heart of the Mayan Biosphere. Guatemala. http://www.miradorbasin.com (Accessed February 2010).

Gibson, C. 2001. Forest Resources: Institutions for Local Governance in Guatemala. In A Framework for Resource Management in the Americas. J. Burger, E. Ostrom, R. B. Norgaard, D. Policansky and B. D. Goldstein (Eds.), pp. 71-90. Washington DC: Island Press.

Gibson, C., J. T. Williams, and E. Ostrom. 2005. Local Enforcement and Better Forests. World Development 33(2): 273-284.

Gliejeses, P. 1989. The Agrarian Reform of Jacobo Arvenz. Journal of Latinamerican Studies 21(3): 453-480.

Goldman, M. 1997. Customs in Common: The Epistemic World of the Common Scholars. Theory and Society 26: 1-37.

Goldman 1998. Privatizing Nature: Political Struggles for the Global Commons. London: TNI/Pluto Press.

Grupo Promotor. 2009. Estrategia nacional para el manejo y conservación de recursos naturales en tierras comunales. Guatemala: CONAP. 
Hale, C. 1996. Resistance and Contradiction: Miskitu Indians and the Nicaraguan State, 1984-1987. Stanford: Stanford University Press.

Harvey, D. 1990. The Condition of Postmodernity. London: Blackwell Publishing Ltd.

Hayes, T. M. 2006. Parks, People, and Forest Protection: An Institutional Assessment of the Effectiveness of Protected Areas. World Development 34(12): 2064-2075.

2007. Does Tenure Matter? A Comparative Analysis of Agricultural Expansion in the Mosquitia Forest Corridor. Human Ecology 35: 733-747.

ICF (Instituto Nacional de Conservación y Desarrollo Forestal). 2011. Anuario Estadístico Forestal 2011. Tegucigalpa: Gobierno de Honduras.

INE (Instituto Nacional de Estadísticas). 2002. XI Censo de Población y VI Habitación. Guatemala: Instituto Nacional de Estadísticas.

Johnson, C. 2004. Uncommon Ground: The "Poverty of History" in Common Property Discourse. Development and Change. 35(3): 407-433.

Larson, A. M. 2010. Making the 'Rules of the Game': Constituting Territory and Authority in Nicaragua's Indigenous Communities. Land Use Policy 27: 1143-52.

Larson, A. M. and J. Mendoza-Lewis. 2012. Decentralisation and Devolution in Nicaragua's North Atlantic Autonomous Region: Natural Resources and Indigenous Peoples' Rights. International Journal of the Commons 6(2): 179-199.

Larson, A. M. and F. Soto, F. (Eds.). 2012. Territorialidady Gobernanza: tejiendo retos en los territorios indígenas de la RAAN, Nicaragua. Managua: Nitlapan-UCA.

Larson, A. M. and J. Mendoza-Lewis. 2009. Desafíos en la Tenencia Comunitaria de Bosques en la RAAN de Nicaragua. Managua: CIFOR/URACCAN/RRI.

Larson, A. M., D. Barry, G. R. Dahal, and C. J. P. Colfer. (Eds.). 2010a. Forests for People: Community Rights and Forest Tenure Reform. London: Earthscan.

Larson, A. M., D. Barry, G. R. Dahal. 2010b. New Rights for Forest Based Communities: Understanding Processes of Forest Tenure Reform. International Forestry Review 12(1): 78-96.

Larson, A. M., P. Cronkleton, D. Barry, P. Pacheco. 2008. Tenure Rights and Beyond: Community Access to Forest Resources in Latin America. Occasional Paper 50. Bogor, Indonesia: CIFOR. 
Lartigue, F. 1993. Comunidad y municipalidad. San Andrés Sajcabajá durante los años 80. In BRETON, A. Representaciones del espacio político en las tierras altas de Guatemala. Cuaderno de Estudios Guatemaltecos, pp. 11-15. Mexico: Centro de Estudios Mexicanos y Centroamericanos.

Lefebvre, H. 1974. The Production of Space. London: Blackwell Publishing Limited.

McCay, B. J. 2002. Emergence of Institutions for the Commons: Contexts, Situations, and Events. In The Drama of the Commons, National Resource Council (Ed.), pp. 361-402. Washington, D.C.: National Academy Press.

McCay, B. J. and J. M. Acheson, 1987. The Question of the Commons. The Culture and Ecology of Communal Resources. Tucson: The University of Arizona Press.

McCay, B. J. and S. Jentoft. 1998. Market or Community Failure? Critical Perspectives on Common Property Research. Human Organization 57(1): 21-29.

Mendoza, J. 2007. Field Reports. Guatemala Highlands. CIFOR/FAUSAC, Unpublished.

Monterroso, I. 2007. Nuevas Tendencias y Procesos que Influyen en el Manejo Comunitario Forestal en la Zona de Usos Multiples Reserva de Biosfera Maya en Peten, Guatemala. CIFOR/ACOFOP, Guatemala City, Guatemala. Unpublished report.

Monterroso, I. and D. Barry. 2012. Legitimation of Forests Rights: The Underpinnings of the Forest Tenure Reform in the Protected Areas of Petén, Guatemala, Conservation and Society 10(2): 136-150.

2010. Sistema de Concesiones Forestales Comunitarias: Tenencia de la tierra, bosques y medios de vida en la Reserva de la Biosfera Maya en Guatemala. Guatemala: Editorial de Ciencias Sociales.

Ortiz, R. D. 1987. Indigenous Rights and Regional Autonomy in Revolutionary Nicaragua. Latin American Perspectives 14(1): 43-66.

Ostrom, E. 2009. A General Framework for Analyzing Sustainability of Socioecological Systems. Science 325: 419-422.

Pacheco, P. and D. Barry. 2009. From Agrarian to Forest Tenure Reform: The Recognition of Forest Rights in Latin America. XIII World Forestry Congress, Buenos Aires, Argentina. 18-23 October. 
Pacheco, P., D. Barry, P. Cronkleton, A. M. Larson and I. Monterroso. 2008. From Agrarian to Forest Tenure Reforms in Latin America: Assessing the Impacts for Local People and Forests. Paper presented at the conference of the International Association for the Study of the Commons (IASC), Cheltenham, England.

Paudel, N. S., I. Monterroso, and P. Cronkleton. 2010. Community Networks, Collective Action and Forest Management Benefits. In Forests for People, A. M. Larson, D. Barry, G. R. Dahal and C. J .P. Colfer (Eds.), pp. 116-136. London: Earthscan.

Peters, P. 1987. Embedded Systems and Rooted Models: The Grazing Lands of Bostwana and the Commons Debate. In The Question of the Commons: The Culture and Ecology of Communal Resources. B. McKay and J. Acheson (Eds.), pp 171-194. Tucson. University of Arizona Press.

PROARCA (Programa Ambiental Regional para Centroamérica) and UICN. 2005. Centroamérica en el límite forestal: Desafíos para la implementación de las políticas forestales en el Itsmo. San José Costa Rica: Programa Areas Protegidas y Mercadeo Ambiental.

Procuraduría General de la República. 2010. Vice Intendencia De La Propiedad, Regimen De Propiedad Comunal (Ley 445). Managua, Mimeo.

Radachowsky, J., V. H. Ramos, R. McNab, E. H. Baur, and E, N. Kazakov. 2012. Forest Concessions in the Mayan Biosphere Reserve: A Decade Later. Forestry Ecology and Management 268: 18-28.

Richards, M. 1997. Common Property Resource Institutions and Forest Management in Latin America. Development and Change 28: 95-117.

RRI and ITTO (Rights and Resources Initiative and International Timber and Trade Organization). 2009. Tropical Forest Tenure Assessment: Trends, Challenges and Opportunities. Prepared for the International Conference on Forest Tenure, Governance and Enterprise: New Opportunities for Central \& West Africa May 25-29, Yaoundé, Cameroon.

Sack, R. D. 1986. Human Territoriality: Its Theory and History. Cambridge: Cambridge University Press.

Soto, F. 2007. Dos experiencias en forestería comunitaria en la RAAN de Nicaragua. In: Manejo de bosques, áreas protegidas y comunidades locales en Nicaragua, Ruiz García, A. (ed.), pp. 171-191. Managua: Nitlapan. 
Stocks, A., B. Mcmahan, and P. Taber. 2007. Indigenous, Colonist, and Government Impacts on Nicaragua’s Bosawas Reserve. Conservation Biology 21(6): 14951505.

Taylor, P. 2009. Conservation, Community, and Culture? New Organizational Challenges of Community Forest Concessions in the Maya Biosphere Reserve of Guatemala. Journal of Rural Studies vol. 26: 173-184.

2012. Multiple Forest Activities, Multiple Purpose Organizations: Organizing for Complexity in a Grassroot Movement in Guatemala's Petén. Forest Ecology and Management 268: 29-38.

Thillet, B., S. Elías, V. Reyna, and C. Sagastume. 2003. Tierras municipales en Guatemala: un desafío para el desarrollo local sostenible. Guatemala: FLACSO Editorial.

Thiusenhusen, W. C. 1989. Searching for the Agrarian Reform in Latin America. London: Routledge.

Tucker, C. M. 1999. Private versus Common Property Forests: Forest Conditions and Tenure in a Honduran Community. Human Ecology 27(2): 202-230.

Tucker, C. M., J. C. Randolph, and E. J. Castellanos. 2007. Institutions, Biophysical Factors and History: An Integrative Analysis of Private and Common Property Forests in Guatemala and Honduras. Human Ecology 35: 259-274.

Van Laerhoven, F. and E. Ostrom. 2007. Traditions and Trends in the Study of the Commons. International Journal of the Commons 1(1): 3-28.

Young, O. R. 2002. Institutional Interplay: The Environmental Consequences of Cross-Scale Interaction. In The Drama of the Commons, National Resource Council (Ed.), pp. 263-292. Washington: National Academy Press. 